\title{
How are soil use and management reflected by soil organic matter characteristics: a spectroscopic approach
}

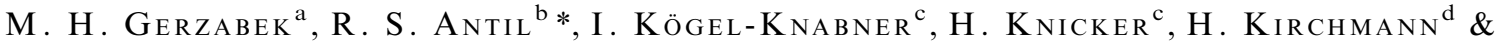 \\ G. HABERHAUER ${ }^{b}$ \\ ${ }^{\mathrm{a}}$ Institute of Soil Research, University of Natural Resources and Applied Life Sciences, Vienna, Peter-Jordan-Strasse $82 b$, A-1190 \\ Vienna, Austria, ${ }^{\mathrm{b}}$ Department of Environmental Research, ARC Seibersdorf Research, A-2444 Seibersdorf, Austria, ${ }^{\mathrm{c}}$ Lehrstuhl für \\ Bodenkunde, Wissenschaftszentrum Weihenstephan für Ernährung, Landnutzung und Umwelt, TU München, D-85350 Freising- \\ Weihenstephan, Germany, and ${ }^{\mathrm{d}}$ Swedish University of Agricultural Sciences, Department of Soil Sciences, Box 7014 , S-750 07 \\ Uppsala, Sweden
}

\begin{abstract}
Summary
We studied the quantitative and qualitative changes of soil organic matter (SOM) due to different land uses (arable versus grassland) and treatments (organic manure and mineral fertilizer) within an agricultural crop rotation in a long-term field experiment, conducted since 1956 at Ultuna, Sweden, on a Eutric Cambisol. The organic carbon (OC) content of the grassland plot was 1.8 times greater than that of the similarly fertilized $\mathrm{Ca}\left(\mathrm{NO}_{3}\right)_{2}$ treated cropped plots. The comparison of two dispersion techniques (a lowenergy sonication and a chemical dispersion which yield inherent soil aggregates) showed that increasing $\mathrm{OC}$ contents of the silt-sized fractions were not matched by a linear increase of silt-sized aggregates. This indicated saturation of the aggregates with OC and a limited capacity of particles to protect OC physically. Thermogravimetric analyses suggested an increase of free organic matter with increasing OC contents. Transmission FT-IR spectroscopy showed relative enrichment of carboxylic, aromatic, $\mathrm{CH}$ and $\mathrm{NH}$ groups in plots with increasing $\mathrm{OC}$ contents. The silt-sized fractions contained the largest SOM pool and, as revealed by ${ }^{13} \mathrm{C}$ NMR spectroscopy, were qualitatively more influenced by the plant residue versus manure input than the clay fractions. Alkyl and O-alkyl $\mathrm{C}$ in the silt-sized fractions amounted to $57.4 \%$ of organic carbon in the animal manure treated plots and $50-53 \%$ in the other treatments.
\end{abstract}

\section{Introduction}

Maintaining or increasing soil organic matter (SOM) is justified both from an agronomic and a climatic perspective because it affects the capacity of the soil to sustain crop growth, is an important factor in decreasing soil compaction and erosion, and is also a source and possible sink of atmospheric $\mathrm{CO}_{2}-\mathrm{C}$ (Paustian et al., 1997). Understanding the processes that control SOM dynamics is the key to SOM management. Land use and agricultural management practices such as crop rotation, soil tillage and organic amendments can affect SOM by influencing both the quantity and quality of crop residues that are returned to the soil; they also influence the rate of decomposition of added residues and native SOM (Gregorich et al., 1994; Haynes \& Beare, 1996).

Correspondence: M.H. Gerzabek. E-mail:martin.gerzabek@boku.ac.at *Present address: Department of Soil Science, CCS Haryana Agricultural University, Hisar 125004, India.

Received 14 April 2005; revised version accepted 8 December 2005
The present paper aims at a better understanding of how organic amendments are stabilized in agricultural crop rotations based on a long-term experiment involving a permanent grassland plot located at Ultuna, Sweden, and started in 1956. Basic data on the turnover of $\mathrm{C}, \mathrm{N}$ and $\mathrm{S}$, temporal changes of $\delta^{13} \mathrm{C}$ and $\delta^{15} \mathrm{~N}$ values in bulk soil and particle size fractions, and changes in physical soil properties and enzyme activities, have been reported previously (Gerzabek et al., 1995, 1997, 1999, 2001a, 2001b, 2002; Haberhauer et al., 2001; Kirchmann et al., 1996; Kirchmann et al., 2004; Kirchmann \& Gerzabek, 1999). Based on an earlier sampling of the Ultuna long-term experiment in 1998, Gerzabek et al. (2001a, b) and Kirchmann et al. (2004) discussed the quantitative changes of organic matter in particle size fractions in detail. The main conclusions were that: (i) input of organic matter of different stability applied at the same rate of OC $\left(2000 \mathrm{~kg} \mathrm{OC} \mathrm{ha}^{-1}\right.$ year $\left.^{-1}\right)$ results in tremendous differences in organic carbon (OC) stocks after four decades of treatment, such that green manure plots exhibit $50 \%$ of the OC contents of peat plots; (ii) the siltsized fraction is the largest carbon storage pool (followed by 
the clay-sized fraction), being very responsive to changes of OC quantity; (iii) a transfer of silt-sized OC to clay-sized OC exists independent of whether organic matter is applied or not; (iv) the clay-sized $\mathrm{OC}$ is the ultimate pool for stabilized OC with greatest natural abundances of ${ }^{13} \mathrm{C}$ and ${ }^{15} \mathrm{~N}$; and (v) the type of treatment does not significantly change bacterial diversity.

The present study aims additionally at chemical characterization of the SOM in bulk soil and size separates, and at linking this information to changes in the SOM pool sizes obtained by physical fractionation. We then extend the study to an adjacent permanent grassland plot. The significantly different SOM contents in the treatments are due to various amounts of organic matter input and varying recalcitrance of this material. We addressed the question of whether the latter is reflected by the SOM characteristics as revealed by Fourier Transformed-Infrared Spectroscopy (FT-IR) (Antil et al., 2005) and ${ }^{13}$ C-NMR spectroscopy (Leifeld \& KögelKnabner, 2005) and thermogravimetric (TG) analysis.

\section{Materials and methods}

\section{Site description and soil sampling}

The field experiment is in central Sweden near Uppsala $\left(60^{\circ} \mathrm{N}\right.$, $17^{\circ} \mathrm{E}$; elevation $14 \mathrm{~m}$ above mean sea level) on a Eutric Cambisol (FAO). The parent material consists of postglacial clay with illite as the main clay mineral. The mean annual temperature is $5.5^{\circ} \mathrm{C}$ and the mean annual precipitation is $660 \mathrm{~mm}$. A complete documentation of the experiment and compilation of data can be found in Kirchmann et al. (1994). In 1956, the soil (0-20 cm depth) had $15 \mathrm{~g} \mathrm{~kg}^{-1}$ of organic $C$, $1.7 \mathrm{~g} \mathrm{~kg}^{-1}$ of total $\mathrm{N}$, and a $\mathrm{pH}$ of 6.6. The present $\mathrm{pH}$ values range from 5.6 to 6.5 in the different treatments. The CEC of selected treatments ranges from 109 (fallow) to 221 (grassland) $\mathrm{mmol}_{\mathrm{c}+} \mathrm{kg}^{-1}$. The plots are very homogeneous with respect to soil texture (coarse sand, 2000-200 $\mu \mathrm{m}, 43 \mathrm{~g} \mathrm{~kg}^{-1}$; fine sand, 200-63 $\mu \mathrm{m}, 195$; silt, 63-2 $\mu \mathrm{m}, 526$; clay, $<2 \mu \mathrm{m}, 236)$. Only the grassland plot exhibits slightly greater clay and smaller sand contents. The area was used as arable land prior to the experiment, animal manure being applied as fertilizer. The experimental design consists of 14 treatments, laid out with four replicates in a randomized block design, the only difference between plots being the type of amendment. The individual plots $(2 \times 2 \mathrm{~m})$ were separated by pressure-treated wooden frames. Four of the treatments, fallow (continuous bare fallow), no $\mathrm{N}$ (plots did not receive $\mathrm{N}$ fertilizers), $\mathrm{Ca}\left(\mathrm{NO}_{3}\right)_{2}\left(80 \mathrm{~kg} \mathrm{~N}^{-1} \mathrm{year}^{-1}\right)$, and animal manure (well decomposed), were selected for the study. The application of animal manure, analysed before use, was based on equal amounts of ash-free $\mathrm{OM}$ amounting to an average of $2000 \mathrm{~kg} \mathrm{C} \mathrm{ha}^{-1}$ year $^{-1}$. The OM was added by hand in the autumn of 1956, 1960 and 1963, and thereafter every second year. Tillage was performed by hand to a depth of $20 \mathrm{~cm}$. Each year in spring, all plots (including bare fallow) received a dressing of $20 \mathrm{~kg} \mathrm{P} \mathrm{ha}^{-1}$ in the form of Ca-superphosphate and $35-38 \mathrm{~kg} \mathrm{~K} \mathrm{ha}^{-1}$ in the form of potassium chloride. The following crops were grown alternatively in an irregular order: cereals (mainly barley, Hordeum vulgare L., with some oat, Avena sativa L., and spring wheat, Triticum aestivum L.) totalling $70 \%$ of the experimental period; rape crops (fodder rape, oilseed rape, Brassica napus L., mustard, Sinapis alba L.) totalling 25\%; and fodder beet (Swedish turnip, Beta vulgaris L. var. Crassa) 5\%. At every harvest, the above-ground portion of the crop was completely removed. Topsoil samples $(0-20 \mathrm{~cm})$ were taken in October 2000 at several places in each plot with an auger, mixed and air-dried. Samples were taken only from four treatments (fallow, no $\mathrm{N}, \mathrm{Ca}\left(\mathrm{NO}_{3}\right)_{2}$ and animal manure) out of the seven treatments commonly followed under the arable system. Three replicate plots were sampled for each of the four treatments. In addition, for comparison with the arable system, we also sampled in an adjacent long-term grass ley (used as a meteorological station) consisting mainly of English ryegrass (Lolium perenne L.) established in 1973; it was fertilized with recommended levels of inorganic blended fertilizer (N, P and K) and regularly cut two to three times each summer with the harvest remaining in place.

Size fractionation was accomplished with sieved samples ( $\leq 2 \mathrm{~mm})$ as described in detail by Stemmer et al. (1998). To minimize destruction of labile particulate OM, the soil-water suspension was dispersed using low-energy sonication $\left(0.2 \mathrm{~kJ} \mathrm{~g}^{-1}\right.$ output energy) and then fractionated by a combination of wet sieving and repeated centrifuging. The microaggregates in the silt-sized fraction are preserved by this method and the impact on enzyme activities is very small (Stemmer et al., 1998). Carbon and nitrogen and the abundance of stable C-isotopes were measured according to Gerzabek et al. (2001a, b). Bulk soil samples were also subjected to chemical dispersion to obtain texture fractions. In contrast to the sonication dispersion, this method destroys microaggregates.

\section{Sample preparation and analysis for transmission FT-IR}

Only the bulk soil and the silt-sized fractions contained enough total OC for FT-IR measurement. The sieved samples were powdered in an agate mill. One $\mathrm{mg}$ of the homogenized agatemilled samples was mixed thoroughly with $100 \mathrm{mg}$ of $\mathrm{KBr}$ (FT-IR grade). A pellet (13 mm diameter) was prepared using a press $\left(15 \mathrm{t} \mathrm{cm}^{-2}\right)$ and immediately put into the sample holder. FT-IR spectra were recorded with a Perkin-Elmer 2000 FT-IR spectrometer at $22 \pm 1{ }^{\circ} \mathrm{C}$. The resolution was set to $4 \mathrm{~cm}^{-1}$ and the operating range was $400-4000 \mathrm{~cm}^{-1}$. In all cases, 20 scans per sample were recorded, averaged for each spectrum and corrected against the spectrum for ambient air as background. Corrected peak heights were obtained using the Perkin-Elmer software Spectrum for Windows 1.3 (1996). 
The parameters for each peak were as follows: Base 1/peak/ Base 2 (all in $\mathrm{cm}^{-1}$ ) 3000/2920/2800; 1800/1730/1700; 1560/ $1510 / 1490 ; 1490 / 1450 / 1400 ; 1190 / 1050 / 900$. In order to quantify the relative changes in the FT-IR spectra and for spectral comparison, relative absorbance (rA) was calculated by dividing the corrected peak height of a distinct peak (e.g. $2920,1730,1630,1510,1450,1370,1270$ or $1050 \mathrm{~cm}^{-1}$ ) by the sum of the heights of all peaks at 2920,1730, 1630, 1510, $1450,1370,1270$ or $1050 \mathrm{~cm}^{-1}$ and multiplying it by 100 ( $\mathrm{rA}=\%$ of the sum of all peak heights from 2920 to $1050 \mathrm{~cm}^{-1}$ ). The band at about $3400 \mathrm{~cm}^{-1}$ is due to the stretching vibration of bonded and non-bonded hydroxyl groups. The band at $2920 \mathrm{~cm}^{-1}$ represents aliphatic $\mathrm{C}-\mathrm{H}$ vibrations of aliphatic methyl and methylene groups (Orlov, 1986). The band at $1630 \mathrm{~cm}^{-1}$ can be assigned to $\mathrm{C}=\mathrm{O}$ vibrations of carboxylates and aromatic vibrations (Stevenson, 1982; Piccolo et al., 1992). The band at $1450 \mathrm{~cm}^{-1}$ can be attributed to $\mathrm{CH}$ and $\mathrm{NH}$ (amide II) bending motions, molecular skeleton vibrations and to $\mathrm{C}-\mathrm{O}$ bond vibrations (Hesse et al., 1995). A sharp and intense band in the $1050 \mathrm{~cm}^{-1}$ region indicates the presence of polysaccharides (Inbar et al., 1989) and Si-O vibrations of clay minerals. Bands at 3630 (Si-O-OH), 800, 780, 700, 650, 590, 530 and $470 \mathrm{~cm}^{-1}$ are due to inorganic materials such as clay and quartz minerals (Orlov, 1986).

\section{Thermal analysis}

The soil samples were subjected to simultaneous thermal analysis (STA), which combines, in one measurement, thermogravimetry (TG) with dynamic differential calorimetry (DSC). The TG method determines the change in the mass of a sample as a function of temperature, whilst DSC monitors difference in heat flow to or from a sample and to or from a reference as a function of temperature, while the sample is subjected to a controlled temperature programme. For all measurements a Netzsch STA 429 (Netzsch, Selb, Germany) instrument with a DSC sample tray was used. Sample cup material was Pt-Rh alloy. Sample size was $50 \mathrm{mg}$ of air-dried bulk soil sample. The soil samples were heated to a maximum of $1050^{\circ} \mathrm{C}$, and the heating rate was $20^{\circ} \mathrm{C}$ minute ${ }^{-1}$. During analysis the oven was flushed with synthetic air at a flow rate of $100 \mathrm{~cm}^{3}$ minutes ${ }^{-1}$.

\section{Solid state ${ }^{13} C-N M R$ spectroscopy}

The chemical composition of the SOM was determined by cross polarization magic angle spinning (CPMAS) ${ }^{13} \mathrm{C}-\mathrm{NMR}$ spectroscopy (Bruker DSX 200 at a frequency of $50.32 \mathrm{MHz}$ ). A ramped ${ }^{1} \mathrm{H}$-pulse starting at $100 \%$ to $50 \%$ of the initial power was given during a contact time of $1 \mathrm{~ms}$ to circumvent spin modulation during the Hartmann-Hahn contact. A pulse delay of $250 \mathrm{~ms}$ and a magic angle spinning speed of $6.8 \mathrm{kHz}$ was used. Between 200000 and 400000 scans were accumulated. Line broadening between 100 and $150 \mathrm{~Hz}$ was applied. The ${ }^{13} \mathrm{C}$-chemical shifts were calibrated relative to tetramethylsilane ( 0 p.p.m.). The areas for different ${ }^{13} \mathrm{C}$ resonances were assigned according to Knicker \& Lüdemann (1995) as follows: $-10-45$ p.p.m. alkyl C, terminal methyl groups, methylene groups in aliphatic rings and chains; 45-110 p.p.m. O-alkyl C, methoxyl groups and C6 of some polysaccharides (45-60 p.p.m.), C2-C5 in hexoses, C of some amino acids, higher alcohols and the aliphatic part of lignin structures (60-90 p.p.m.), anomeric C of carbohydrates, C-2, C-6 of syringyl units of lignin (90-110 p.p.m.); 110-160 p.p.m. aromatic $\mathrm{C}$, aromatic $\mathrm{C}-\mathrm{H}$ and $\mathrm{C}-\mathrm{C}$ carbons and guaiacyl $\mathrm{C}-2$, C-6 in lignin (110-140 p.p.m.), aromatic COR or CNR groups (140-160 p.p.m.); 160-220 p.p.m. carboxyl C, carboxyl C, carbonyl $\mathrm{C}$ and amide $\mathrm{C}$. Replicates of NMR-measurements were not performed due to the long measurement times. However, former studies showed standard deviations of less than $10 \%$ (Diekow et al., 2005).

\section{Statistical analysis}

We undertook an analysis of variance (ANOVA) with STATISTICA 6.0 (at http://www.statsoft.com). Within the STATISTICA 6.0, after calculating ANOVA, we applied the Duncan multiple range test to compare significance differences within the treatments. Single linkage agglomerative cluster analysis with Euclidian distances was performed.

\section{Results}

Table 1 gives an overview of OC and $\mathrm{N}$ contents in bulk soils and particle-size fractions in the differently treated plots. Both organic $\mathrm{C}$ and total $\mathrm{N}$ concentrations in bulk soil samples from the upper $20 \mathrm{~cm}$ of the profile responded significantly to 44 years of different treatments under both the arable and grassland system. Compared with 1956 (15 $\mathrm{g} \mathrm{OC} \mathrm{kg}^{-1}$ soil, $1.7 \mathrm{~g} \mathrm{~N} \mathrm{~kg}^{-1}$ soil) the fallow treatment lost approximately $31 \%$ and $37 \%$ of its original organic $\mathrm{C}$ and total $\mathrm{N}$ concentrations, respectively, whereas the animal manure treated plots and the grassland system exhibited a much greater SOC level. The SOC and total $\mathrm{N}$ concentrations remained fairly constant in plots treated with $\mathrm{Ca}\left(\mathrm{NO}_{3}\right)_{2}$. $\mathrm{OC}$ and $\mathrm{N}$ accumulated significantly under the grassland system compared with the arable plots in general and with the $\mathrm{Ca}\left(\mathrm{NO}_{3}\right)_{2}$ plot in particular (which closely approximates the fertilization regime of the grassland).

When comparing arable and grassland systems with respect to $\mathrm{C}$ and $\mathrm{N}$ distribution in particle-size fractions, the largest differences were found in the sand-sized fractions, with much greater portions of OC present in grassland. Differences in $\mathrm{N}$ were less distinct in this respect. In the grassland system, sand fractions exhibited greater $\mathrm{C}: \mathrm{N}$ ratios than in the arable system. However, only small differences were observed in the fine fractions (silt and clay) of both systems. 
Table 1 Response of OC and $\mathrm{N}$ contents of bulk soil and particle-size fractions to different long-term treatments 44 years after start of the field experiment. (means \pm standard errors, $n=3$ replicate plots)

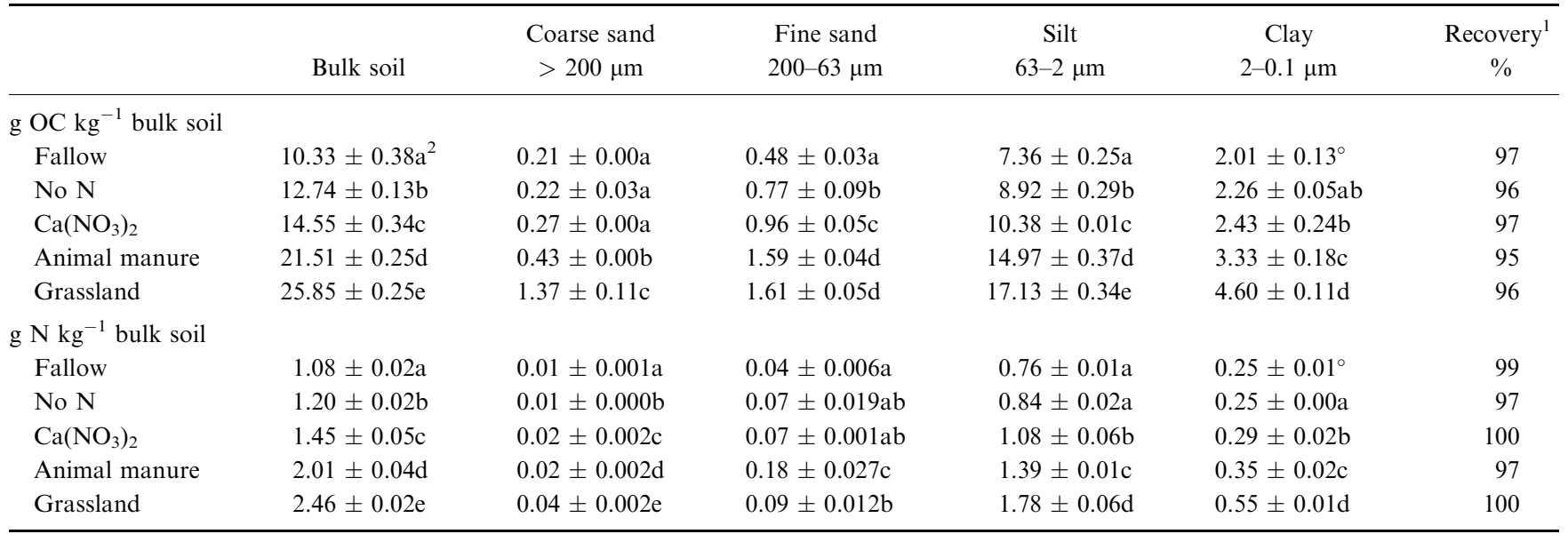

${ }^{1}$ Sum of fractions of bulk soil $\mathrm{C}$ and $\mathrm{N}$.

${ }^{2}$ Different letters within columns indicate significance at $P<0.05$.

\section{Characteristics of soil organic matter}

Previous papers showed that the ${ }^{13} \mathrm{C}$ and ${ }^{15} \mathrm{~N}$ natural abundances in bulk soil and particle size fractions were influenced significantly by the management systems and the treatments within the arable system (Gerzabek et al., 1997, 2001a, b). In 1956 , organic $\mathrm{C}$ in bulk soil had an initial $\delta^{13} \mathrm{C}$ value of $-26.3 \%$ and $\delta^{15} \mathrm{~N}$ values were around $8.4-8.9 \%$. The grassland topsoil, sampled in 2000, had the following mean $\delta^{13} \mathrm{C}$ values (in \% $\pm \mathrm{SD}, n=3$ ): bulk, $-27.12 \pm 0.05$; coarse sand, $-27.74 \pm 0.26$; fine sand, $-27.88 \pm 0.04$; silt, $-26.99 \pm 0.04$; clay, $-26.43 \pm 0.16$. The $\delta^{15} \mathrm{~N}$ values were: bulk, $9.36 \pm 0.25$; coarse sand, $8.00 \pm 0.07$; fine sand, $8.13 \pm 0.04$; silt, $10.01 \pm 0.14$; clay, $9.31 \pm 0.22$. Compared with the fallow plots $\left({ }^{13} \mathrm{C}=-25.9 \%\right.$ o \pm 0.02 in bulk soil $)$ and the initial soil, the grassland plots exhibited more negative delta values for $\mathrm{C}$. The grassland plot showed significantly smaller $\delta^{13} \mathrm{C}$ values than all arable plots.

The $\delta^{13} \mathrm{C}$ values of the grassland plot are dominated by the plant residue input, and shoots had $\delta^{13} \mathrm{C}$ values of approximately $-27.1 \pm 0.9 \%$ (Gerzabek et al., 1997). These values are best reflected by the coarse size separates. Cluster analysis of all isotopic data of particle size separates (not shown) revealed least similarity of the isotopic pattern of the grassland system with all other treatments.

Figure 1 shows examples of transmission FT-IR spectra of bulk soil under fallow and grassland. In general, the spectra of the bulk soil and the silt-sized fraction in both systems are comparable and show the same peak pattern. Intense bands were recorded at about $3400 \mathrm{~cm}^{-1}$ (bonded and non-bonded hydroxyl groups) and at $1630 \mathrm{~cm}^{-1}(\mathrm{C}=\mathrm{O}$ vibrations of carboxylates and aromatic vibrations). Other clearly visible bands were at $2920 \mathrm{~cm}^{-1}$ (aliphatic C-H vibrations) and at $1450 \mathrm{~cm}^{-1}$ (CH and NH (amide II) bending motions, molecular skeleton vibrations and carbon oxygen bond vibrations). A sharp and intense band was recorded in the $1050 \mathrm{~cm}^{-1}$ region (polysaccharides and Si-O vibrations of clay minerals). The changes in the relative absorption of selected bands in the bulk soil and silt fraction as a response to treatments within the arable vs. the grassland system are summarized in Table 2 . The arable and grassland systems differed significantly and these differences were similar in both the bulk soil and the silt fractions. The relative absorption of the band at $1630 \mathrm{~cm}^{-1}$ (carboxylic groups and aromatic groups) and $1450 \mathrm{~cm}^{-1}(\mathrm{CH}$ and $\mathrm{NH}$ (amide II) groups) was greater in the grassland than in the arable system. However, the relative absorption of the band at $2920 \mathrm{~cm}^{-1}$ (C-H vibrations) was greater in the arable system, especially in the bulk soil. For the band at $1050 \mathrm{~cm}^{-1}$ (Si-O vibrations), relative absorption was less in the grassland versus the arable system.

The TG-analysis yielded reasonable estimates for soil organic matter (Table 3), which were positively correlated

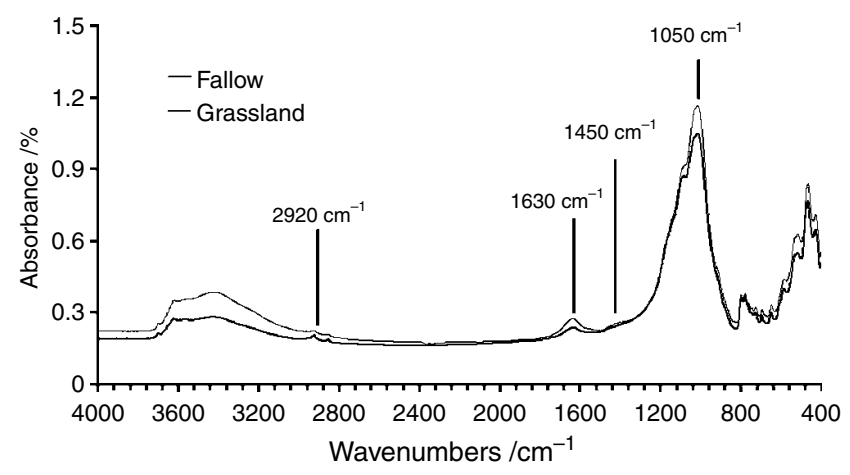

Figure 1 FTIR spectra of bulk soil of the fallow treatment and the grassland plot. 
Table 2 Mean relative absorbance ( $n=2$ replicate plots, 20 scans per sample) in percentage of the sum of all selected peak heights of the FT-IR spectra of bulk soil and silt-sized fraction after 44 years of different treatments

\begin{tabular}{llll}
\hline & & Relative absorbance as percentage of sum of selected peaks \\
\cline { 2 - 4 } & $2920 / \mathrm{cm}^{-1}$ & 1630 & 1450 \\
\hline Bulk soil & & & $0.11 \mathrm{~b}$ \\
Fallow & $1.35 \mathrm{~g}^{1}$ & $2.67 \mathrm{a}$ & $0.12 \mathrm{bc}$ \\
$\mathrm{No} \mathrm{N}$ & $0.62 \mathrm{~cd}$ & $2.90 \mathrm{ab}$ & $0.15 \mathrm{bcd}$ \\
$\mathrm{Ca}\left(\mathrm{NO}_{3}\right)_{2}$ & $0.77 \mathrm{ef}$ & $3.26 \mathrm{bc}$ & $0.17 \mathrm{~cd}$ \\
Animal manure & $0.81 \mathrm{f}$ & $3.16 \mathrm{bc}$ & $0.26 \mathrm{e}$ \\
Grassland & $0.67 \mathrm{de}$ & $4.80 \mathrm{~d}$ & $96.36 \mathrm{c}$ \\
Silt-sized fraction & & & $0.04 \mathrm{a}$ \\
Fallow & $0.41 \mathrm{a}$ & $2.46 \mathrm{a}$ & $0.06 \mathrm{a}$ \\
No N & $0.50 \mathrm{ab}$ & $2.50 \mathrm{a}$ & $0.10 \mathrm{~b}$ \\
Ca(NO & $3.46 \mathrm{c}$ & $95.86 \mathrm{bc}$ \\
Animal manure & $0.55 \mathrm{bc}$ & $3.37 \mathrm{c}$ & $94.27 \mathrm{a}$ \\
Grassland & $0.56 \mathrm{bc}$ & $4.77 \mathrm{~d}$ & $97.09 \mathrm{~d}$ \\
\hline
\end{tabular}

${ }^{1}$ Different letters within columns indicate significance at $P<0.05$.

with the $\mathrm{OC}$ contents derived from the elemental analyser. The $\mathrm{SOM}$ values derived from the weight loss in two peaks (mean temperature $c .330^{\circ} \mathrm{C}$ and $440^{\circ} \mathrm{C}$ ) showed the following regression function with the $\mathrm{OC}$ values obtained by measurements using the elemental analyser: $\operatorname{SOM}(\%)=1.68$ OC $(\%)$ $\left(R^{2}=0.95, n=6, P<0.01\right)$. Note that the temperature interval of the main peak shifted between the differently treated soil samples. The end temperature remained fairly constant at $416^{\circ} \mathrm{C}$, whereas the starting temperature varied between 200 and $223^{\circ} \mathrm{C}$ and tended to decrease with increasing SOM contents.

Figure 2 provides two solid-state ${ }^{13} \mathrm{C}$ NMR spectra that are representative for the silt- and clay-sized fractions. The siltsized fractions are dominated by O-alkyl C (110-45 p.p.m.) followed by aromatic C (160-110 p.p.m.) (Table 4). The clear signal between 160 and 140 p.p.m. is probably caused by O-aryl $\mathrm{C}$ and indicates the presence of lignin derivatives. This is supported by the pronounced resonance line between

Table 3 TG DSC ${ }^{-1}$-analysis of selected bulk soil samples. Weight loss and the temperature interval of the main weight-loss peak. $n=3$

\begin{tabular}{lcccc}
\hline & & \multicolumn{2}{c}{ Characteristics of the main peak (DSC) } \\
\cline { 3 - 5 } & $\begin{array}{c}\text { Organic matter } \\
\text { (weight loss) } \\
\% \pm \mathrm{SE}^{1}\end{array}$ & from $^{\circ} \mathrm{C}^{2}$ & to ${ }^{\circ} \mathrm{C}$ & $\begin{array}{c}\text { Temperature } \\
\text { of maximum } \\
\text { height } /{ }^{\circ} \mathrm{C}\end{array}$ \\
\hline Fallow & $1.9 \pm 0.02$ & 223 & 416 & 338 \\
$\mathrm{Ca}\left(\mathrm{NO}_{3}\right)_{2}$ & $2.4 \pm 0.03$ & 213 & 416 & 342 \\
Animal & $3.7 \pm 0.04$ & 200 & 417 & 339 \\
manure & & & & \\
Grassland & $4.6 \pm 0.05$ & 201 & 416 & 337 \\
\hline
\end{tabular}

\footnotetext{
${ }^{1}$ Standard error.

${ }^{2}$ Mean standard deviation: $1.9^{\circ} \mathrm{C}$.
}

60 and 45 p.p.m. in the chemical shift region of methoxyl C. Given the $\mathrm{C} / \mathrm{N}$ ratios between 8 and 11 (calculated from Table 1), some $\mathrm{N}$-alkyl $\mathrm{C}$ is also contributing to this chemical shift region. The main difference in the SOM composition of the
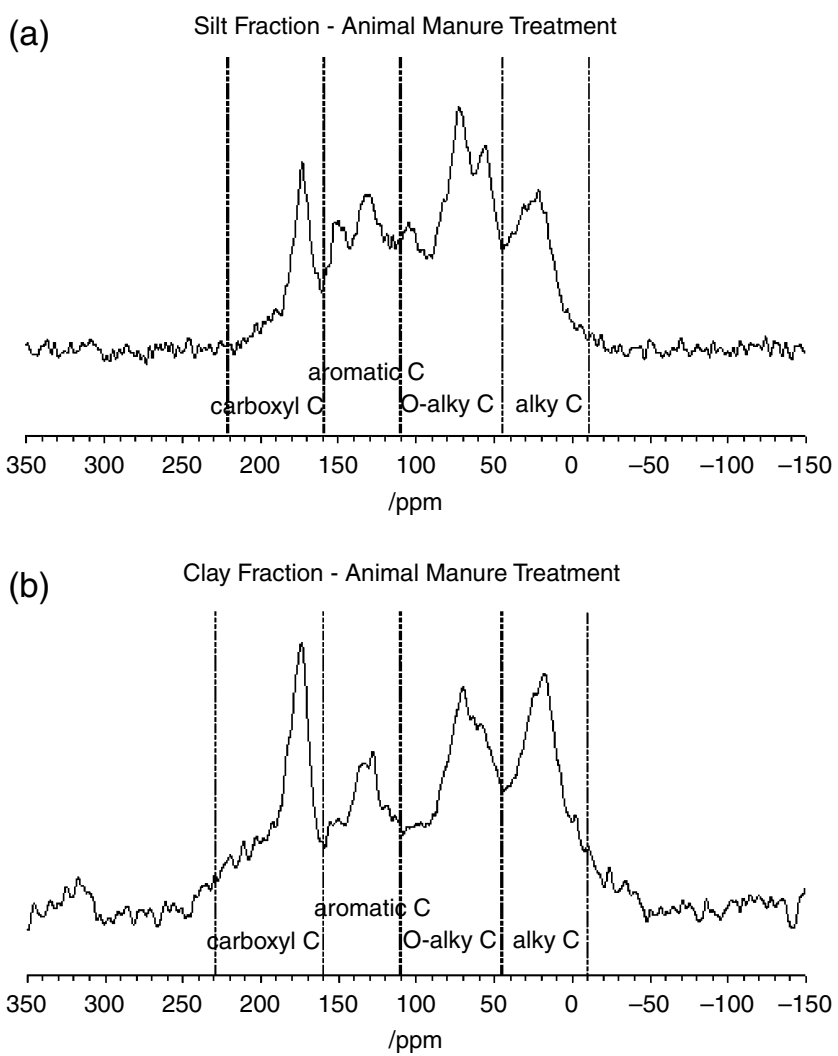

Figure 2 CPMAS ${ }^{13} \mathrm{C}$-NMR spectra of the silt- and clay-sized particles of the animal manure treatment 44 years after start of the field experiment. 
Table 4 Relative contribution of different $\mathrm{C}$ groups in percentage of SOC of the different fractions based on the intensity distribution in the CPMAS ${ }^{13} \mathrm{C}$-NMR spectra

Alkyl O-alkyl Aromatic Carboxyl \& Carbonyl

\begin{tabular}{lcccc}
\hline & Alkyl & O-alkyl & Aromatic & Carboxyl \& Carbonyl \\
\hline Silt-sized fraction & & & & \\
$\quad$ Fallow & 18.1 & 32.2 & 29.2 & 20.6 \\
No N & 20.6 & 32.4 & 26.9 & 20.0 \\
Ca(NO$)_{2}$ & 19.2 & 33.1 & 27.7 & 20.0 \\
Animal manure & 22.1 & 35.3 & 23.2 & 19.5 \\
Grassland & 20.6 & 32.8 & 23.5 & 23.1 \\
Clay-sized fraction & & & & \\
Fallow & 26.6 & 27.9 & 21.2 & 24.3 \\
No N & 16.3 & 29.4 & 30.5 & 23.8 \\
Ca(NO NO $_{2}$ & 20.4 & 29.6 & 27.9 & 22.1 \\
Animal manure & 26.4 & 30.2 & 19.5 & 24.0 \\
Grassland & 21.1 & 33.2 & 25.7 & 20.1 \\
\hline
\end{tabular}

silt-sized fractions caused by the different treatments is a smaller aromatic-C content in the grassland (24\%) and animal manure plot $(23 \%)$ than in the samples from fallow, no $\mathrm{N}$ and $\mathrm{Ca}\left(\mathrm{NO}_{3}\right)_{2}(27-29 \%)$. Comparable aromatic-C proportions of $20 \%$ and $28 \%$ were recently reported for the silt-sized fractions of a grassland soil and an arable soil in southern Germany (Leifeld \& Kögel-Knabner, 2005). No trend can be discerned with respect to the content of alkyl C (45-0 p.p.m.) and carboxyl C (220-160 p.p.m.). For clay-sized fractions pronounced differences were found in the aromatic- $\mathrm{C}$ contents, which were small for animal manure (19.5\%) and fallow $(21.2 \%)$ and greater for the other treatments (more than $25 \%$ ). A similar pattern of carbon type distribution was found for fallow and animal manure.

The organic matter composition of the silt- and clay-sized fraction differed within a given treatment. The largest relative deviations in this respect were up to $7 \%$ alkyl-C, $8 \%$ aromatic$\mathrm{C}$ and 5\% carboxyl-C for fallow, fallow and animal manure, respectively, In most cases carboxyl-C was more and O-alkyl less prominent in the clay-sized particles than in the silt-sized separates.

\section{Discussion}

Particle-size fractionation provides evidence for chemical stabilization of soil organic matter in addition to physical protection

Following the conceptual model of Six et al. (2002), a further development of an earlier model provided by Jenkinson \& Rayner (1977), the protective capacity of a given soil consists of two components: chemical stabilization based on the interaction of SOM with clay and silt particles and physical protection based on compartmentalization between substrate and microbes due to microaggregate formation. Much evidence has been provided for the concept of a 'protective capacity' in soils (e.g. Hassink, 1997; Stemmer et al., 1999). In contrast, the idea of a selective enrichment of recalcitrant molecule classes contained in plant residues like lignin or the phenols in soil derived during decomposition of fresh OM has received less support in the most recent literature (e.g. Rumpel et al., 2004).

Our findings clearly support Hassink's (1997) proposed decrease in additional 'protective capacity' of soil particles with increasing organic matter content in soil. Figure 3 shows the relationship between the OC content in silt-sized particles and the absolute amount of silt-sized aggregates. These were obtained as differences between the ultrasonication (data not shown) and the chemical dispersion pretreatment (texture fractions according to the 'Material and methods' section), the first preserving stable microaggregates and the latter yielding primary silt particles. The curve plateau indicates saturation of silt-sized particles with organic matter. The additional $\mathrm{OC}$ in the silt fraction (OC in the silt fraction of the respective treatment minus $\mathrm{OC}$ in the silt fraction of the fallow treatment) increased from no- $\mathrm{N}$ to $\mathrm{Ca}\left(\mathrm{NO}_{3}\right)_{2}$, animal manure and grassland (260, 336, 423, $514 \mathrm{mg} \mathrm{OC}^{-1}$ additional stable microaggregates, as compared with the fallow treatment, respectively). Thus, most of the additional OC present in the silt-sized fraction is probably not stabilized through physical protection, but must be present as particulate OC or stabilized by adsorption on mineral surfaces. Recently it was shown that especially oxide surfaces contribute to the adsorption mechanism (Wiseman \& Püttmann, 2005). The TG analysis underlines this. Bonding of SOM with inorganic material may affect the temperature of the main weight-loss peak, causing a shift to higher temperatures (Jocteur Monrozier et al., 1991). In fact, the thermal transition of SOM occurred at a higher temperature if SOM contents were small (e.g. bare fallow; Table 3). The smaller thermal stability of SOM in samples with greater

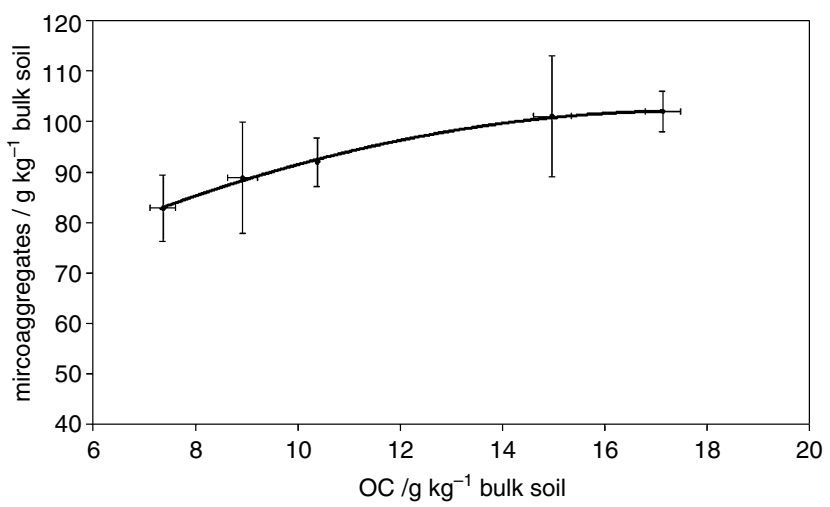

Figure 3 Relation of microaggregates (y, difference between ultrasonication and chemical dispersion pretreatment) and OC present in the silt-sized fraction. $\left(y=-0.1779 \mathrm{x}^{2}+6.3142 \mathrm{x}+46.123, R^{2}=0.998\right.$, $P<0.001)$; bars are \pm one standard error. Data points from left to right: fallow, no $\mathrm{N}, \mathrm{Ca}\left(\mathrm{NO}_{3}\right)_{2}$, animal manure, grassland. 
OC content could indicate a larger portion of free OM not occluded in mineral associations.

In contrast to the arable plots, the coarse sand fraction in the grassland plot contained considerably more $\mathrm{OC}$ and $\mathrm{N}$. This observation is supported by findings of Leifeld \& KögelKnabner (2005) and Desjardins et al. (1994) and is an additional indicator for the slower breakdown of fresh OM in the grassland topsoil; this is further supported by the wide $\mathrm{C}: \mathrm{N}$ ratio of the OM in the coarse sand fraction (as calculated from Table 1).

A general decrease in $\mathrm{C}: \mathrm{N}$ ratios with smaller particle sizes has been reported by various authors (Stemmer et al., 1998; Kandeler et al., 1999; Gerzabek et al., 2001b). Small C:N ratios measured in fine fractions indicate increasing humification of the SOM in the silt- and clay-sized fractions versus the sand fraction. An additional explanation could be the enrichment of N-rich microbial metabolites in the silt and clay fractions. Such N-rich metabolites are known to be rapidly included in soil humic fractions (Knowles \& Barro, 1981). In the Ultuna long-term experiment, microbial biomass was greater in silt- and clay-sized fractions than in the fine-sand fraction. This could be attributed to a greater microbial diversity in fine fractions, as shown by a terminal restriction fragment length polymorphism analysis, cloning and sequencing of 16 s-RNA genes (Sessitsch et al., 2001).

\section{Differences in FT-IR and NMR spectra}

Transmission FT-IR spectroscopy yielded significantly different results for the various treatments (Table 2). Cluster analysis of bulk soil and silt-sized fractions (not shown) using the spectral data from 3000 to 2800,1800 to 1560,1490 to 1400 , and 1190 to $900 \mathrm{~cm}^{-1}$, revealed a clear difference between the arable and grassland system (Figure 1). Within the arable system, the closest similarity was found between animal manure and $\mathrm{Ca}\left(\mathrm{NO}_{3}\right)_{2}$ plots and between no- $\mathrm{N}$ and fallow plots. The increase in the relative absorption of the bands at $1630 \mathrm{~cm}^{-1}$ (carboxylic groups and aromatic groups) and $1450 \mathrm{~cm}^{-1}$ with increasing SOM contents indicated a relative enrichment of carboxylic, aromatic, $\mathrm{CH}$ and $\mathrm{NH}$ (amide II) groups in bulk soil and silt-sized samples. The OC contents of the soil samples could be sufficiently described by three FT-IR bands $\left(2920+1630+1450 \mathrm{~cm}^{-1}\right.$, Figure 4$)$. We can conclude that changes in organic moieties as indicated by aliphatic $\mathrm{C}-\mathrm{H}$ vibrations $\left(2920 \mathrm{~cm}^{-1}\right), \mathrm{C}=\mathrm{O}$ vibrations of carboxylates and aromatic vibrations $\left(1640 \mathrm{~cm}^{-1}\right)$ and $\mathrm{CH}$ and $\mathrm{NH}$ (amide II) bending motions $\left(1450 \mathrm{~cm}^{-1}\right)$ contribute significantly to total SOC content changes. The present study is the first to show a quantitative relationship between FT-IR bands and SOM in bulk mineral soil; to date, this was only known in organic soil horizons (e.g. Haberhauer et al., 2000).

The ${ }^{13} \mathrm{C}-\mathrm{NMR}$ data provided more comprehensive information about the chemical characteristics of SOM than the FTIR spectra. A series of 10 cluster analyses taking into account

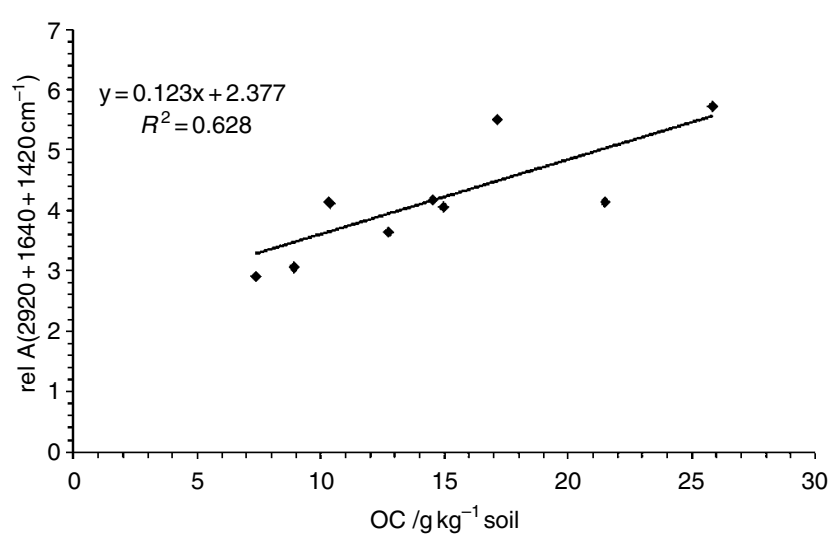

Figure 4 Relation of relative absorbances (FT-IR bands 2920, 1630 and $1450 \mathrm{~cm}^{-1}$ ) with the OC contents of bulk soils and the silt-sized fractions. $P<0.05$

either specific spectral areas (not shown) or total spectra from -10 to 220 p.p.m. (Figure 2) were performed. For the siltsized particles, about 3-6\% more aromatic $\mathrm{C}$ was detected in plots receiving only root residues or no organic input (fallow, no $\mathrm{N}$ and $\left.\mathrm{Ca}\left(\mathrm{NO}_{3}\right)_{2}\right)$ than in the grassland and animal manure plots. Greater aromaticity in the silt fraction, which reflected land-use change from grassland to arable, was also found for a sandy Dystric Cambisol in southern Germany (Leifeld \& Kögel-Knabner, 2005), and a subtropical Acrisol in Brazil (Diekow et al., 2005). The latter was explained by changes in the microbial communities that alter the quality of the biochemical products.

Compared with the silt-sized fractions of the other treatments, the animal manure shows a slightly greater O-alkyl C content (Table 4), possibly reflecting a greater input of straw residues with the manure. The amount of microbial biomass probably does not result in greater sugar contents because biomass carbon does not differ significantly between the treatments discussed here (Witter et al., 1993).

Another distinct between-treatment difference in the chemical composition of the silt-sized fractions was the content of total alkyl $\mathrm{C}$; the values were $57.4 \%$ in the animal manure treatment and $50-53 \%$ in the other treatments (calculated from Table 4). Correlations and cluster analysis showed the greatest similarity between those treatments not receiving any organic inputs or only roots (fallow, no-N and $\mathrm{Ca}\left(\mathrm{NO}_{3}\right)_{2}$ ) (Figure 4, Table 5).

In the clay-sized fractions, the fallow and animal manure treated plots were the most similar. $\mathrm{Ca}\left(\mathrm{NO}_{3}\right)_{2}$ showed some similarity to the last two treatments, and no-N and grassland were clearly separated (Figure 5). These observations are quantified by the correlation coefficients shown in Table 5 . Note also the difference between the NMR patterns in silt- and clay-sized separates of the fallow and animal manure treatment (Table 4). We found a larger difference between the siltsized samples $(r=0.87)$, but closer similarity between the clay fractions $(r=0.95)$. NMR-spectra correlation of the 
Table 5 Correlation coefficients $(r)$ of CPMAS ${ }^{13}$ C-NMR of the region $-10-220$ p.p.m. $(n=1212$, all values are significant at $P<0.05)$. GL, grassland; NoN, no nitrogen plot; $\mathrm{CA}, \mathrm{Ca}\left(\mathrm{NO}_{3}\right)_{2}$; FA, fallow; $\mathrm{AM}$, animal manure

\begin{tabular}{|c|c|c|c|c|c|}
\hline & Silt AM & Silt FA & Silt NoN & Silt CA & Silt GL \\
\hline Silt AM & - & 0.87 & 0.92 & 0.92 & 0.94 \\
\hline Silt FA & 0.87 & - & 0.94 & 0.96 & 0.89 \\
\hline Silt CA & 0.92 & 0.96 & 0.97 & - & 0.94 \\
\hline \multirow[t]{2}{*}{ Silt GL } & 0.94 & 0.89 & 0.93 & 0.94 & - \\
\hline & Clay AM & Clay FA & Clay NoN & Clay CA & Clay GL \\
\hline Clay NoN & 0.51 & 0.57 & - & 0.93 & 0.89 \\
\hline Clay CA & 0.62 & 0.66 & 0.93 & - & 0.88 \\
\hline Clay GL & 0.72 & 0.73 & 0.89 & 0.88 & - \\
\hline
\end{tabular}

clay- versus the silt-sized fraction in the fallow treatment was poorer $(r=0.59)$ than the correlation between the respective
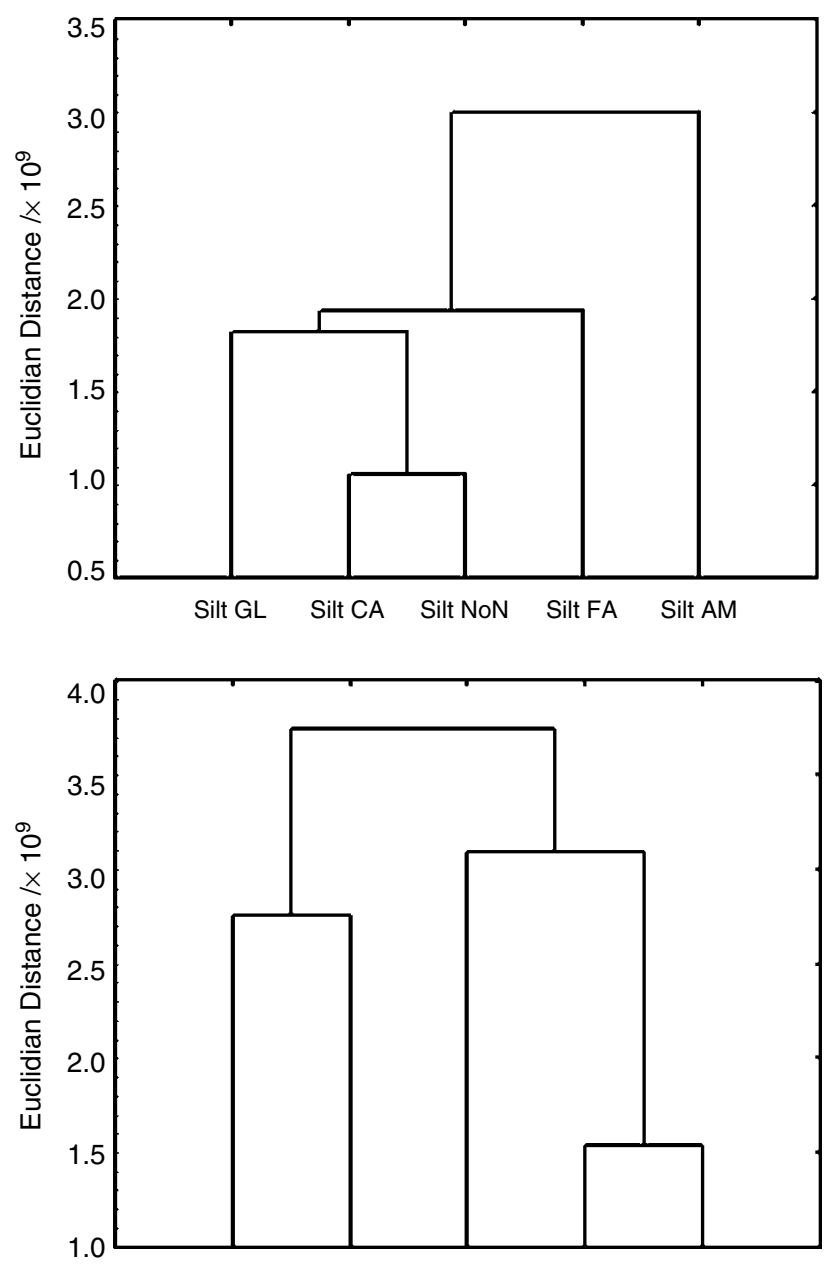

Clay GL Clay NoN Clay CA Clay FA Clay AM

Figure 5 Cluster analysis of CPMAS ${ }^{13} \mathrm{C}-\mathrm{NMR}$ spectra of the silt- (a) and clay- (b) sized particles. GL, grassland; NoN, not nitrogen fertilized plot; $\mathrm{CA}, \mathrm{Ca}\left(\mathrm{NO}_{3}\right)_{2}$; FA, fallow; AM, animal manure. fractions of the fallow and animal manure treatments. Considering that the long-term experiment was under standard agricultural cultivation, including manuring prior to the experiment in 1956, the clay-sized fraction of the bare fallow plots (no OM since 1956) apparently preserved the typical pattern of these animal manure inputs for more than 44 years. The other plots at least received plant residue input; this also changed the SOM characteristics in the clay fraction compared with the start of the experiment.

\section{Conclusions}

1 The grassland system in which the OM input was only through crop residues had greater SOC and $\mathrm{N}$ concentrations, and significantly smaller natural abundances of ${ }^{13} \mathrm{C}$, than the arable plots. The NMR spectra showed similarities with those plots receiving only plant residue input.

2 FT-IR spectroscopy revealed a relative enrichment of carboxylic, aromatic, $\mathrm{CH}$ and $\mathrm{NH}$ (amide II) groups in plots with increasing $\mathrm{OC}$ contents.

3 Increasing OC contents in the silt fraction were not followed by a linear formation of silt-sized aggregates (clay-OM associations). Thus, OC in the silt-sized fraction was only partly stabilized by physical protection. Particulate OC and adsorption to mineral surfaces were increasingly important, which was also corroborated by thermogravimetric analyses.

$4{ }^{13} \mathrm{C}$-NMR patterns revealed that SOM in silt-sized fractions was more influenced by the amount of plant residue inputs than SOM in clay fractions.

\section{Acknowledgements}

We thank the Austrian Science Fund (Fonds zur Förderung der wissenschaftlichen Forschung) for funding this bilateral project. We are grateful to G. Gaggl for assisting with the TG analysis. The authors thank Pär Hillsström for the careful and responsible maintenance of the long-term experiment. We thank the anonymous reviewers for their valuable comments. 


\section{References}

Antil, R.S., Gerzabek, M.H., Haberhauer, G. \& Eder, G. 2005. Longterm effects of cropped vs fallow and fertilizer amendments on soil organic matter. 1. Organic carbon. Journal of Plant Nutrition and Soil Science, 168, 108-116.

Desjardins, T., Andreux, F., Volkoff, B. \& Cerri, C.C. 1994. Organic carbon and ${ }^{13} \mathrm{C}$ contents in soils and soil size-fractions, and their changes due to deforestation and pasture installation in eastern Amazonia. Geoderma, 61, 103-118.

Diekow, J., Mielniczuk, J., Knicker, H., Bayer, C., Dick, D.P. \& Kögel-Knabner, I. 2005. Soil organic matter composition of a subtropical Acrisol as influenced by land use, no-till cropping systems and $\mathrm{N}$ fertilization, assessed by $\mathrm{CP} / \mathrm{MAS}{ }^{13} \mathrm{C} \mathrm{NMR}$ spectroscopy. European Journal of Soil Science, 56, 705-715.

Gerzabek, M.H., Haberhauer, G., Kandeler, E., Sessitsch, A. \& Kirchmann, H. 2002. Response of organic matter pools and enzyme activities in particle size fractions to organic amendments in a longterm field experiment. Developments in Soil Science, 28, 329-344.

Gerzabek, M.H., Haberhauer, G. \& Kirchmann, H. 2001a. Soil organic matter pools and carbon-13 natural abundance in particlesize fractions of a long-term agricultural field experiment receiving organic amendments. Soil Science Society of America Journal, 65, 352-358.

Gerzabek, M.H., Haberhauer, G. \& Kirchmann, H. 2001b. Nitrogen distribution and ${ }^{15} \mathrm{~N}$ natural distribution in particle size fractions of a long-term agricultural field experiment. Journal of Plant Nutrition and Soil Science, 164, 475-481.

Gerzabek, M.H., Kirchmann, H., Haberhauer, G. \& Pichlmayer, F. 1999. The response of soil nitrogen and ${ }^{15} \mathrm{~N}$ natural abundances to different amendments in a long-term experiment at Ultuna, Sweden. Agronomie, 19, 457-466.

Gerzabek, M.H., Kirchmann, H. \& Pichlmayer, F. 1995. Response of soil aggregate stability to manure amendments in the Ultuna long-term soil organic matter experiment. Zeitschrift für Pflanzenernährung und Bodenkunde, 158, 257-260.

Gerzabek, M.H., Pichlmayer, F., Kirchmann, H. \& Haberhauer, G. 1997. The response of soil organic matter to manure amendments in a long-term experiment in Ultuna, Sweden. European Journal of Soil Science, 48, 273-282.

Gregorich, E.G., Carter, M.R., Angers, D.A., Monreal, C.M. \& Ellert, B.H. 1994. Towards a minimum data set to assess organic matter quality in agricultural soils. Canadian Journal of Soil Science, 74, 367-385.

Haberhauer, G., Feigl, B., Gerzabek, M.H. \& Cerri, C.C. 2000. FT-IR spectroscopy of organic matter in tropical soils: changes induced through deforestation. Applied Spectroscopy, 54, 221-224.

Haberhauer, G., Pfeiffer, L., Gerzabek, M.H., Kirchmann, H., Aquino, A.J.A. \& Tunega, D. et al. 2001. Response of sorption processes of MCPA to the amount and origin of organic matter in a longterm field experiment. European Journal of Soil Science, 52, 279-286.

Hassink, J. 1997. The capacity of soils to preserve organic C and N by their association with clay and silt particles. Plant and Soil, 191, 77-87.

Haynes, R.J. \& Beare, M.H. 1996. Aggregation and organic matter storage in meso-thermal, humid soils. In: Structure and Organic Matter Storage in Agricultural Soils (eds M.R. Carter \& B.A. Stewart), pp. 213-262. Advances in Soil Science. CRC Lewis, Boca Raton, Florida.
Hesse, M., Meier, H. \& Zeeh, B. 1995. Spektroskopische Methoden in der Organischen Chemie. Georg Thieme Verlag, Stuttgart.

Inbar, Y., Chen, Y. \& Hadar, Y. 1989. Solid-state carbon-13 nuclear magnetic resonance and infrared spectroscopy of composted organic matter. Soil Science Society of America Journal, 53, 1695-1701.

Jenkinson, D.S. \& Rayner, J.H. 1977. The turnover of soil organic matter in some of the Rothamsted classical experiments. Soil Science, 123, 298-305.

Jocteur Monrozier, L., Ladd, J.N., Fitzpatrick, R.W., Foster, R.C. \& Raupach, M. 1991. Components and microbial biomass content of size fractions in soils of contrasting aggregation. Geoderma, 49, 37-62.

Kandeler, E., Palli, S., Stemmer, M. \& Gerzabek, M.H. 1999. Tillage changes microbial biomass and enzyme activities in particle-size fractions of a Haplic Chernozem. Soil Biology Biochemistry, 31, $1253-1264$.

Kirchmann, H. \& Gerzabek, M.H. 1999. Relationship between soil organic matter and micropores in a long-term experiment at Ultuna, Sweden. Journal of Plant Nutrition and Soil Science, 162, 493-498.

Kirchmann, H., Haberhauer, G., Kandeler, E., Sessitsch, A. \& Gerzabek, M.H. 2004. Effects of level and quality of organic matter input on soil carbon storage and biological activity in soil: synthesis of a long-term experiment. Global Biogeochemical Cycles, 18, 38-46.

Kirchmann, H., Persson, J. \& Carlgren, K. 1994. The Ultuna LongTerm Soil Organic Matter Experiment, 1956-91. Reports and Dissertations 17. .Department of Soil Science, Swedish University of Agricultural Sciences, Uppsala.

Kirchmann, H., Pichlmayer, F. \& Gerzabek, M.H. 1996. Sulfur balances and sulfur-34 abundance in a long-term fertilizer experiment. Soil Science Society of America Journal, 59, 174-178.

Knicker, H. \& Lüdemann, H.D. 1995. N-15 and C-13 CPMAS and solution NMR-studies of $\mathrm{N}-15$ enriched plant material during 600 days of microbial degradation. Organic Geochemistry, 23, 329-341.

Knowles, R. \& Barro, L. 1981. Contribution of bacterial cell nitrogen to soil humic fractions. Plant and Soil, 61, 243-250.

Leifeld, J. \& Kögel-Knabner, I. 2005. Soil organic matter fractions as early indicators for carbon stock changes under different land-use. Geoderma, 124, 143-155.

Orlov, D.S. 1986. Humus Acids of Soil. Balkema, Rotterdam.

Paustian, K., Collins, H.P. \& Paul, E.A. 1997. Management controls on soil carbon. In: Soil Organic Matter in Temperate Agroecosystems: Long-Term Experiments in North America (eds E.A. Paul, K. Paustian, E.A. Elliott \& C.V. Cole), pp. 15-49. CRC Press, Boca Raton, Florida.

Piccolo, A., Zaccheo, P. \& Genevini, P.G. 1992. Chemical characterization of humic substances extracted from organic-waste-amended soils. Bioresource Technology, 40, 275-282.

Rumpel, C., Eusterhues, K. \& Kögel-Knabner, I. 2004. Location and chemical composition of stabilized organic carbon in topsoil and subsoil horizons of two acid forest soils. Soil Biology Biochemistry, 36, 177-190.

Sessitsch, A., Weilharter, A., Gerzabek, M.H., Kirchmann, H. \& Kandeler, E. 2001. Microbial population structures in soil particle size fractions of a long-term fertilizer field experiment. Applied Environmental Microbiology, 67, 4215-4224.

Six, J., Conant, R.T., Paul, E.A. \& Paustian, K. 2002. Stabilization mechanisms of soil organic matter: implications for C-saturation of soils. Plant and Soil, 241, 155-176. 
Stemmer, M., Gerzabek, M.H. \& Kandeler, E. 1998. Soil organic matter and enzyme activity in particle size fractions of soils obtained after low-energy sonication. Soil Biology Biochemistry, 30, 9-17.

Stemmer, M., von Lützow, M., Kandeler, E., Pichlmayer, F. \& Gerzabek, M.H. 1999. The effect of maize straw placement on mineralization of $\mathrm{C}$ and $\mathrm{N}$ in soil particle size fractions. European Journal of Soil Science, 50, 73-86.
Stevenson, F.J. 1982. Humus Chemistry. Wiley, New York.

Wiseman, C.L.S. \& Püttmann, W. 2005. Soil organic carbon and its sorptive preservation in central Germany. European Journal of Soil Science, 56, 65-76.

Witter, E., Martensson, A.M. \& Garcia, F.V. 1993. Size of the soil microbial biomass in a long-term field experiment as affected by different N-fertilizers and organic manures. Soil Biology Biochemistry, 25, 659-669. 